\title{
The changing form of overconfidence and its effect on growth expectations at the early stages of startups
}

\author{
László Szerb $\mathbb{D}$ ・ Zsófia Vörös
}

Accepted: 8 November 2019 / Published online: 30 November 2019

(C) The Author(s) 2019

\begin{abstract}
In this article, we attempt to explain the failure of many studies to show a link between entrepreneurs' beliefs in their entrepreneurial skills and the actual or expected growth of their venture. By using Frese and Gielnik's action-characteristics model of entrepreneurship as an analytical framework and analyzing Global Entrepreneurship Monitor Adult Population Survey data, we show that entrepreneurs' perceived entrepreneurial skills are consistently inflated over the different phases of the startup, albeit in different ways. Depending on the typical form of overconfidence, the link between skill beliefs and growth expectations may be mediated by expectations about competitive advantages. Moreover, the huge drop in growth expectations is not associated with a drop in perceived skills; instead other entrepreneurial expectations also become more realistic and their effect strengthens with experience.
\end{abstract}

Keywords Self-efficacy - Overconfidence $\cdot$ Growth expectations · Entrepreneurship · Action-characteristics theory $\cdot$ GEM

JEL classification D91 $\cdot$ L26 $\cdot$ M13

L. Szerb $(\bowtie)$

Faculty of Business and Economics, University of Pécs, Rákóczi út 80 , Pécs H-7622, Hungary

e-mail: szerb.laszlo@ktk.pte.hu

Z. Vörös

Faculty of Business and Economics, University of Pécs, Rakóczi út 80, Pécs H-7622, Hungary

e-mail: voros.zsofia@ktk.pte.hu

\section{Introduction}

There is no doubt about the importance of entrepreneurship in economic development and growth (e.g., Acs et al. 2018). However, only a small fraction of ventures expand dynamically and these firms contribute disproportionately to growth in employment (BERR 2008; Henrekson and Johansson 2010; Nanda 2016). The intensity of the ongoing debate on what makes a highgrowth venture reflects both the importance of the issue and the ambiguity in current explanations (e.g., Audretsch 2012).

One possible influential factor of high business growth is the confidence of owners/managers in their entrepreneurial skills. The potential role of perceived skills in outcome expectations and actions is frequently examined and explained in the framework of motivational theories, such as the Theory of Planned Behaviour (Fishbein \& Ajzen 2011). In this theory, behavioral intention is an immediate predecessor of actual behavior and skill beliefs are drivers of the behavioral intention and outcome expectations. In this paper, we investigate the relationship between perceived entrepreneurial skills and the expected growth of business ventures.

To label perceived skills required to accomplish entrepreneurial tasks - based on Bandura's Social Learning Theory (2006) - the notion of entrepreneurial selfefficacy (ESE) was proposed. In general, outcomes of actions and outcome expectations depend largely on how people evaluate their general or more specific task-related skills (see Bandura 2006; Fishbein \& 
Ajzen 2011). However, in the field of entrepreneurship, the relationship between perceived entrepreneurial skills and actual growth seems to vary largely from negative to positive (see Miao et al. 2017 for summary). What could cause the observed inconsistencies? This is the question we aim to study.

Our study is also driven by recent results on overconfidence (Moore and Schatz 2017). In general, studies on the effects of ESE do not look into the connection between self-reported skill beliefs and the actual skill level of entrepreneurs. At the same time, another line of research concentrates on entrepreneurial overconfidence. Even though the definition of entrepreneurial overconfidence varies (e.g., Åstebro et al. 2014; Forbes 2005; Koellinger et al. 2007; Zhang and Cueto 2017), entrepreneurial overconfidence is mostly described and assessed as someone's miscalibrated and inflated beliefs in his entrepreneurial abilities-i.e., the inflated form of ESE - and the overestimation of positive outcomes of his business decisions (Hogarth and Karelaia 2012; Invernizzi et al. 2016; Malmendier and Tate 2015; Ucbasaran et al. 2010). Indeed, cognitive researchers have suggested that entrepreneurs are especially predisposed to make biased decisions. Among the biases observed, overconfidence is considered to be the most prevalent and harmful (e.g., Baron 1998; Costa et al. 2017; Cooper et al. 1988).

In the entrepreneurship research, the concept of overconfidence is typically used and assessed as a trait-like, unified construct, even though the psychology literature recently started distinguishing three forms of overconfidence affecting behavior at different times and in different ways (Moore and Schatz 2017). In fact, the necessity of making this distinction among the diverse forms of overconfidence in the entrepreneurship research has already been pointed out by Zhang and Cueto (2017). Recent studies also suggest that overconfidence may be domain-dependent and domain-specific knowledge, experience and skills may influence its extent and effects (Moore and Schatz 2017; Muthukrishna et al. 2018). Thus, based on theories of overconfidence, we investigate how perceived entrepreneurial skills and their exaggeratedness fluctuate and how the form of overconfidence changes with entrepreneurial experience. We also look at how the transformations of the perceived entrepreneurial skills affect growth expectations. To the best of our knowledge, there are no empirical analyses on the experience related variations of the exaggeratedness of perceived entrepreneurial skills, the form of entrepreneurial overconfidence, and their link to growth expectations. Indeed, several researchers argued the need for more insight into how and what entrepreneurs learn from their experience (Politis 2005) and to examine the relationship between experience and decisional biases and entrepreneurial characteristics (Baron and Markman 2005; Rauch and Frese 2007; Zhang and Cueto 2017). Newmann et al. (2018) specifically appeal for study in to the fluctuations of ESE, the negative effect of ESE, and to link ESE to related constructs, such as overconfidence.

We position our investigation into Frese and Gielnik's action-characteristics model (Frese and Gielnik 2014). This model seems to be a suitable framework for our research as it examines the contributors of entrepreneurial success that is defined as survival and growth on the market. Additionally, it suggests that how inflated skill beliefs are and the form of entrepreneurial overconfidence depend on entrepreneurial experience. Moreover, it implies that the strength and consistency of the effect of perceived entrepreneurial skills on growth expectations may fluctuate with experience and other entrepreneurial expectations may modify that relationship too.

In this paper, after the reconciliation of the literature on perceived entrepreneurial skills and entrepreneurial overconfidence, we present new empirical evidence on the forms of entrepreneurial overconfidence, its variations with experience and relationship with growth expectations during the early stages of the business lifecycle. To test out hypotheses, we use Global Entrepreneurship Monitor (GEM) data on differently experienced businesses.

Our results show that early stage entrepreneurs are overconfident but the form of their overconfidence in their entrepreneurial skills changes with experience. At market entry, entrepreneurs' skill beliefs are not based on judgments relative to others. At the baby stage of business development, entrepreneurs' overconfidence is mostly based on relative judgments vis-á-vis their peers. The effect of overconfidence on growth expectation is then partially mediated by beliefs about competitive advantages. Moreover, the huge drop in growth expectations is not associated with a fall of perceived skills; instead other entrepreneurial expectations also become more realistic and the effects of these strengthen. These results reveal the importance of differentiating the forms of overconfidence and taking into account the experience of business owners when looking at the effects of perceived skills. Further implications to policy makers 
and practitioners are discussed in the concluding remarks.

\section{Literature review}

Our theoretical framework, Frese and Gielnik's (2014) action characteristics model imply that the perceived entrepreneurial skills-actual growth relationship should be divided into two parts. The perceived entrepreneurial skills-growth expectations link and the growth expectations-actual growth relations should be investigated separately to fully understand the effect of perceived entrepreneurial skills on actual growth and how experience moderates this relationship. Thus, in this section, we revise the theoretical and empirical research on the effect of perceived entrepreneurial skills on market entry decisions, growth expectations, and actual growth separately. We also revisit what we know about the form of entrepreneurial overconfidence and how entrepreneurial experience comes into play.

\subsection{Effect of perceived entrepreneurial skills on market entry}

The positive relationship between ESE and firm creation seems to be well substantiated in the literature (e.g., Barbosa et al. 2007; Fuller et al. 2018; Piperopoulos and Dimov 2015). However, perceptions are not passively mirrored elements of the world and their relationships, but actively created, subjective interpretations that often result in biased models in a person's mind (e.g., Johnson-Laird 2005). Indeed, a large number of theoretical and empirical studies have concluded that nascent entrepreneurs' perceived entrepreneurial skills are inflated (e.g., Baron 1998; Costa et al. 2017; Cooper et al. 1988). And as one would expect, market entry was shown to be positively associated with entrepreneurial overconfidence as well (Gutierrez and Astebro 2016; Hayward et al. 2006; Koellinger et al. 2007; Navis and Ozbek 2017; Wu and Knott 2006).

Unrealistically optimist expectations at market entry are also well documented. The belief of the widespread entrepreneurial overconfidence is often based on the famous study by Cooper et al. (1988) and other research showing that market entries are not driven by judgments based on objective success probabilities (e.g., Hall and Woodward 2010). According to the U.S. Bureau of Labor Statistics, only about half of all new businesses survive 5 years. In contrast, Cooper et al. (1988) revealed that $81 \%$ of business founders believe that the likelihood of the success of their venture is over $70 \%$.

2.2 The evolution of ESE, ESE-growth expectations, and ESE-actual growth relationships

Learning-by-doing is the primary way entrepreneurs learn (Frese and Gielnik 2014; Minniti and Bygrave 2001; Politis 2005; Shane 2003). Thus, entrepreneurs become more skilled as they gather experience by running their business. However, we know very little about how entrepreneurs' beliefs in their entrepreneurial skills - i.e., their ESE - change with experience. We were able to identify one study showing that entrepreneurial experience fosters ESE (Lee et al. 2016).

The relationship of ESE with entrepreneurial success after market entry is also less straightforward than the effect of ESE on venture creation. In general, higher selfefficacy is associated largely with higher performance (Bandura 2006). Entrepreneurs with high ESE were theorized to perform better than their peers because of setting more challenging goals, investing more effort to achieve those goals, and being more persistent when meeting obstacles (e.g., Markman et al. 2002; Trevelyan 2011). However, in a meta-analysis of 26 studies, Miao et al. (2017) found only a moderate correlation (0.309) between ESE and company performance, with several pieces of research ascertaining a weak or even negative relationship.

Moreover, only a handful of studies have examined the ESE-growth expectations link separately (see Levie and Autio 2013), and the majority of these could not confirm it (Bosma and Schutjens 2009; Tominc and Rebernik 2007; Stenholm et al. 2013). Bosma and Schutjens (2009) could not establish a link between high ESE and the rate of ambitious early stage entrepreneurship across European regions. The analyses of Stenholm et al. (2013) did not show a connection between the cognitive dimensions of entrepreneurship - including ESE-and entrepreneurial aspirations. We could locate only one study on Latin American countries (Lecuna et al. 2017) that empirically associated ESE with growth expectations.

2.3 The evolution of entrepreneurial overconfidence and its effects on expected and actual growth

How entrepreneurial experience relates to the evolution of entrepreneurial overconfidence is not empirically 
evidenced (see for summary Zhang and Cueto 2017). Many studies confirm the existence of entrepreneurial overconfidence at later stages of the life cycle (Betzer et al. 2017; Invernizzi et al. 2016; Lowe and Ziedonis 2006; Shepherd 2009; Simon and Houghton 2003) and theoretical models usually suggest a gradual decrease in entrepreneurial overconfidence (Gervais and Odean 2001; Jovanovic 1982; Konon and Kritikos 2015).

In contrast, empirical research abounds on the direct effect of entrepreneurial overconfidence on actual firm performance. In contrast to ESE, typically the negative impact of entrepreneurial overconfidence is accentuated in this respect. Entrepreneurial overconfidence was suggested or shown to lead to excessive risk-taking in entrepreneurial decisions (Grichnik 2008; Hayward et al. 2006; Simon and Houghton 2003), to prolonging or failing to diagnose poor performance (Lowe and Ziedonis 2006; Shepherd 2009), to investing in failing projects (Betzer et al. 2017), and, finally, to destroying the company's value - leading to failure (Invernizzi et al. 2016; Hayward et al. 2006; Wu and Knott 2006). At the same time, based on motivational theories, some scholars believe that entrepreneurial overconfidencejust like ESE - helps to overcome failures, increase resilience, and leads toward more ambitious goals (Everett and Fairchild 2015; Hayward et al. 2010; Simon and Shrader 2012). For example, Everett and Fairchild (2015) proposed a U-shaped curve to describe the relationship between entrepreneurial overconfidence and performance.

To the best of our knowledge, entrepreneurial overconfidence - assessed as a perception of own entrepreneurial skills - was not empirically linked to growth expectations (see Hermans et al. 2015).

\subsection{Forms of entrepreneurial overconfidence}

Even if nascent entrepreneurs' overconfidence may be considered axiomatic, entrepreneurship research has yet to go beyond considering entrepreneurial overconfidence as a single construct (see Zhang and Cueto 2017). Even though the psychology literature distinguishes three separate forms of overconfidence (Moore and Schatz 2017), entrepreneurship studies examining the forms of overconfidence at market entry are rare.

The first type of overconfidence is overestimation, believing that one is better than reality justifies. In general, people tend to overestimate the outcome of complex, difficult tasks while underestimating their performance in very easy ones (Lichtenstein and Fischhoff 1977). The second and the most common form of overconfidence is overplacement. Overplacement is the distorted belief that one is better than others (Chamorro-Premuzic 2013). Overplacement works in the opposite direction to overestimation across task difficulty levels, i.e., overplacement is typical in very easy tasks (Moore and Healy 2008). Thus, overestimation and overplacement are not mutually exclusive but overestimation may be coupled with underplacement.

And finally, the third and the most persistent form of overconfidence is overprecision. This manifests itself in a too narrow a confidence interval on the truth, i.e., too high certainty in one's own beliefs.

In this study, we are interested in the first two forms of entrepreneurial overconfidence as those represent absolute or relative skill estimates. By market game experiments, Bolger et al. (2008) found that market entry is mostly driven by overestimation. In their experiments, disregarding market size and the potential number of competitors, together with exaggerated absolute skill beliefs, were responsible for too many market entries in skill-based games. Contradicting Bolger et al. (2008), Moore and Cain's (2007) results suggest that on the average, market entries are based on overplacement. Combining the psychology and entrepreneurship literature, Cain et al. (2015) showed that people choose markets considered easy-to-enter. According to their argumentation, as a result of that self-selection process, nascent entrepreneurs feel the tasks associated with market entry relatively simple and easy. Thus, overplacement may be responsible for excessive market entries into competitive fields with low boundaries and high fluctuations.

According to our knowledge, the forms of entrepreneurial overconfidence have not been examined at later stages of the business life-cycle yet.

\section{Theory and hypotheses}

As mentioned in the introduction, we use Frese and Gielnik's action-characteristics meta-theoretical framework model (Frese and Gielnik 2014) for our investigation.

This theory claims that entrepreneurs develop mental models from - among other elements - goals, plans, expected results, and growth to form their action 
characteristics. They regulate their actions based on those action characteristics. Perceived entrepreneurial skills influence success via action characteristics. In turn, external factors may modify the action characteristics or the action characteristics-success link.

In this section, we formulate our hypotheses on the evolution of perceived entrepreneurial skills and the forms of entrepreneurial overconfidence in the early stages of business start-ups. We also explore the moderating role of entrepreneurial experience in the relationship between perceived entrepreneurial skills and growth expectations.

\subsection{Nascent entrepreneurs' perceived entrepreneurial skills}

Supposing that nascent entrepreneurs' perceived entrepreneurial skills are inflated is in line with theories and the vast majority of empirical studies. Still, there is a debate on the relative or absolute nature of overconfidence at market entry (Bolger et al. 2008; Moore and Cain 2007). On the one hand, the results and argumentation of Cain et al. (2015) seem reasonable. One may think that as entrepreneurs usually select easyto-enter markets, they feel the task of starting a venture relatively easy and overplace themselves. On the other hand, the participants of Moore and Cain's (2007) experiments received immediate feedback about their peers. This protocol may prompt thinking about own skills relative to others. Moreover, we think that even if most entrepreneurs create new ventures in fields considered relatively easy-to-enter, they may feel running their new venture a very hard task. Our theoretical framework suggests that nascent entrepreneurs make decisions based mostly on their subjective judgments in a new, uncertain, and complex environment where they have to consciously regulate all their actions (see also Gartner et al. 1992). First time, nascent entrepreneurs learn how to create a company and acquire resources but pose little competency and no experience in growing a company. Dealing with the first sales and generating the first profits on sales are activities characterized by uncertainties related to own skills, the task and the environment (see Frese and Gielnik 2014). Frese and Gielnik (2014) add that because of the novelties, any entrepreneurial tasks must be consciously regulated, i.e., tasks require attention and effort. Thus, on an individual level, establishing and running a new business can be a difficult task even in a market with low-entry boundaries.
The perceived hardness of the errands of a nascent entrepreneur may be very different from how the market is judged globally, relatively to other markets. In this case, the psychological theories on overconfidence (Lichtenstein and Fischhoff 1977) would support Bolger et al. (2008), i.e., that market entry is driven by overestimation. If the task is very hard, it is easy to overestimate our skills.

However, if we accept that overestimation could be coupled with underplacement, one may ask why nascent entrepreneurs enter the market if they think their abilities are inferior to their competitors. The answer is what Camerer and Lovallo (1999) called reference group neglect. The authors found that, at market entry, people know about the other players but they do not seem to care about them or their abilities (see also Bolger et al. 2008).

Thus, we formulate the following hypothesis:

\section{H1: Nascent entrepreneurs mainly overestimate themselves. Thus, on average, when they evaluate their skills they do not compare themselves to their peers. Their overconfidence is absolute.}

\subsection{Effect of experience on entrepreneurial overconfidence during the early stages of entrepreneurship}

After starting up a venture, the next phase of a successful business is the period of growth. Nascent entrepreneurs have to offer or do something in a novel way to generate profit. By just replicating things, without any competitive advantage, it is hard to survive in the market (Frese and Gielnik 2014; Foss and Klein 2012; Porter 1985) that is characterized by a fundamental selection during the early years of ventures. About half of the ventures fail and half of the entrepreneurs give up that occupation within the first three to five years. Changes are more intense in the first year of start-ups (Quatraro and Vivarelli 2014).

According to Frese and Gielnik (2014), the key to entrepreneurial success is being active. Actions continuously produce feedbacks and considering the feedback is the way entrepreneurs learn through their experience. Active feedback seeking and processing, active approach to mistakes, deliberate learning, and practicing help entrepreneurs to transform their experience into knowledge and lead them toward success. 
In general, entrepreneurship scholars also recognize that learning-by-doing is the foremost way entrepreneurs learn (Frese and Gielnik 2014; Minniti and Bygrave 2001; Politis 2005; Cope and Watts 2000; Shane 2003). Politis (2005) mentions two important abilities that entrepreneurs learn by running their business: general managerial skills, i.e., managing finances, sales or the organization itself, and handling liabilities of newness, i.e., problem solving, planning, and organizing (see also Shane 2003).

As far as we know, the effect of experience within the same venture on the exaggeratedness of entrepreneurial overconfidence is not fully evidenced and explained (see e.g., Newmann et al. 2018). In general, research shows that experience represents not only greater domain-specific knowledge but a higher level of metacognition, computational thinking, and decision strategy (Chi et al. 1982; Hershey et al. 2003), i.e., better calibration of the relevant skills and knowledge. Models of entrepreneurial learning usually also suppose that nascent entrepreneurs gradually learn about their entrepreneurial abilities over time by considering the responses to their actions (Jovanovic 1982; Konon and Kritikos 2015).

Taken together, we hypothesize that, as experience is gained, overconfidence in entrepreneurial skills becomes gradually more closely related to the real skill level of early stage entrepreneurs. Therefore, early-stage entrepreneurs gradually become less overconfident. The update of skill beliefs is realized through the mechanism of continuous feedback production of active entrepreneurs. However, the feedback may be confusing as entrepreneurs need to reformulate their skill beliefs based on inferred information from the generated revenue, market successes, or failures (see Konon and Kritikos 2015). In addition, if entrepreneurs apply the Bayes Rule to reassess their skill beliefs, they overrate successes and underrate failures (Gervais and Odean 2001).

Frese and Gielnik (2014) also suggest that by becoming more skilled in running their business, entrepreneurs can allocate more resources to their metacognitive processes, i.e., to evaluate their knowledge and skills. In addition, out framework theory also implies that considering feedbacks are key activities to survive in the market. Thus, a more experienced cohort of entrepreneurs is supposed to be more skilled and less overconfident not just because of the experiential learning but because of the fundamental market selection during the early years.
H2: At later stages of business life cycle, entrepreneurs are less overconfident than nascent entrepreneurs.

There is a debate on the form of overconfidence at market entry, and, according to our knowledge, researchers have not directly examined the form of overconfidence in the later stages of business life cyle. We hypothesize that, even if nascent entrepreneurs overestimate their entrepreneurial skills (see H1), entrepreneurs' overconfidence will become relative to others after some experience. First, Frese and Gielnik (2014) imply that entrepreneurs are learning-by-doing. Therefore, they will perform their entrepreneurial tasks more and more routinely. Results concerning the association between task difficulty and the forms of overconfidence suggest that overplacement is typical with easier tasks (Chamorro-Premuzic 2013; Lichtenstein and Fischhoff 1977; Moore and Schatz 2017). Second, while becoming more skilled in managing their business and coping with newness, entrepreneurs gain industry-specific experience (Politis 2005). By running their business, entrepreneurs learn about not only their entrepreneurial skills but also collect information on the logic of the market they act on and their competitors. In fact, entrepreneurs make inferences regarding their entrepreneurial skills based on revenue and market signals (see under H2). As competitors play a significant role in business outcomes (i.e., competitive advantage is relative), entrepreneurs' judgments on their entrepreneurial skills must contain an increasing amount of information related and relative to their peers.

Hence, at some point, entrepreneurs will overplace themselves. In addition, theories suggest that those entrepreneurs who are able and willing to estimate their skills relative to their competitors-i.e., concentrate on their competitive advantage - are more likely to survive.

H3: After market entry, early-stage entrepreneurs will mostly overplace themselves at some point.

\subsection{Relationship between entrepreneurial} overconfidence and growth expectation during the early stages of life cycle

In line with motivation theories, Frese and Gielnik's framework theory (2014) suggests that higher perceived entrepreneurial skills are associated with higher growth 
expectations. In fact, entrepreneurship researchers often use the outcome expectations themselves as proxies for beliefs in entrepreneurial skills (e.g., Cooper et al. 1988; Invernizzi et al. 2016). However, perceived skills must be differentiated from outcome expectations. The perceived skill designates a judgment on capacities to execute tasks and outcome expectations are projections on the outcome of those tasks.

Based on our theoretical framework, we believe that perceived skills positively associate with growth expectations but as entrepreneurs gain experience, their beliefs on competitive advantages may drive changes in growth expectations more and more powerfully.

First, we supposed (H3) that entrepreneurs will overplace at some point. In this case, as the service or product offered is the manifestation of entrepreneurial skills, product, or service novelty beliefs - i.e., beliefs in competitive advantages - must mediate the effect of entrepreneurial skill beliefs on growth expectations.

Second, when starting a business, nascent entrepreneurs encounter uncertainties not merely concerning their skills, but also the value of their ideas, the growth potential of their business and the income it will generate. As described under H3, the feedback and update of entrepreneurial beliefs are primarily based on market signals, such as sales and consumer satisfaction. As the primary source of the belief update during learning-by-doing is coming in from market feedback, expected growth and beliefs on competitive advantages may become considerably more realistic even if overconfidence weakens slightly or does not weaken at all.

Besides, in general, as a venture ages, decision processes become more comprehensive and group based. These processes result in more informed and less biased decisions (Forbes 2005; Kugler et al. 2012).

\section{H4: Entrepreneurial overconfidence is positively associated with growth expectations. However, the effect of beliefs about competitive advan- tages will become stronger with experience.}

\section{Research design, applied variables, and methodology}

Entrepreneurs acquire specific knowledge and skills at the different stages of the business life cycle (Frese and
Gielnik 2014; Politis 2005; see the theory and hypotheses section for further explanation). Hence, the life cycle stage of a business may represent the experience of its owners/managers and the comparison of business ventures at the different stages of their life cycle makes it possible to study the interactions between entrepreneurial beliefs, expectations, and experience.

The Global Entrepreneurship Monitor Adult Population Survey (GEM APS) is a representative, national survey to measure and examine entrepreneurial attitudes, abilities, aspirations, activities, and their influential factors across the business life cycle in a uniformly designed fashion (Reynolds et al. 2005). In this study, we use GEM data to test our hypotheses.

\subsection{Applied variables and data}

To test our hypotheses, the pooled 2011-2014 GEM APS individual data set was used. For the purpose of this study, we used only the working population of innovation-driven countries aged between 18 and 64 . Habitual (both portfolio and sequential) business owners were omitted from the analyses.

To separate the businesses into age groups, we followed GEM categorization (Reynolds et al. 2005):

1. Nascent start-ups are those whose owners are actively involved in setting up a business they will own or co-own. These businesses have not paid salaries, wages, or made any other payments to the owners for more than 3 months.

2. Baby businesses have paid salaries, wages, or made other payments to the owners for more than three but less than 42 months. Their owners are actively participating in the management of the business.

3. Established businesses have paid salaries, wages, or made other payments to the owners - who also manage their business - for more than 42 months.

Nascent and baby business owners are considered early stage entrepreneurs.

Table 1 lists the variables we use to test our hypothesis. Table 2 contains the number and percentage of entrepreneurs with positive beliefs by the stages of the business life cycle.

In all models, we filtered out the socioeconomic background effects. That is to say that, we have controlled out for education level, work status, gender, and age (Autio 
Table 1 GEM variables directly linked to our hypothesis

\begin{tabular}{|c|c|c|c|c|}
\hline & $\begin{array}{l}\text { Type of the } \\
\text { variable }\end{array}$ & $\begin{array}{l}\text { Variable } \\
\text { name }\end{array}$ & Variable description & Possible values \\
\hline $\begin{array}{l}\text { Entrepreneurial } \\
\text { experience }\end{array}$ & IV & LICY & $\begin{array}{l}\text { The stage of the business life cycle } \\
\text { (see the definitions above) }\end{array}$ & $\begin{array}{l}\text { (1) Nascent, (2) Baby, } \\
\text { (3)Established }\end{array}$ \\
\hline $\begin{array}{l}\text { Perceived } \\
\text { entrepreneurial } \\
\text { skills }\end{array}$ & DV or IV & SKILL & $\begin{array}{l}\text { Start-up skills: Respondent claiming } \\
\text { to possess the required knowledge/skills } \\
\text { to start a business. }\end{array}$ & (0) No, (1)Yes \\
\hline $\begin{array}{l}\text { Product novelty } \\
\text { expectations }\end{array}$ & DV or IV & NEWP & $\begin{array}{l}\text { New product: The number of (potential) } \\
\text { customers that will consider product } \\
\text { new/unfamiliar. }\end{array}$ & $\begin{array}{l}\text { (0) Nobody, (1) Few or all } \\
\text { customers }\end{array}$ \\
\hline Growth expectations & DV & GROWTH $^{\mathrm{a}}$ & $\begin{array}{l}\text { Growth aspiration: Businesses having } \\
\text { high job growth expectation over } 10 \text { more } \\
\text { employees and } 50 \% \text { in } 5 \text { years. }\end{array}$ & $\begin{array}{l}\text { (0) Lower than } 50 \% \text { and } 10 \\
\text { employee, (1) Over } 50 \% \text { and } \\
10 \text { employee }\end{array}$ \\
\hline
\end{tabular}

${ }^{a}$ We should mention here that our measure of growth combines a relative and an absolute growth value. So, well-established large and small start-up business ventures have about the same chance to reach the applied threshold value.

2011; BERR 2008; Terjesen and Szerb 2008). We considered entrepreneurs as individuals acting embedded in their country (Acs et al. 2014; Autio 2011). Thus, in all our models, we have accounted for the effect of country. Opportunity beliefs and risk propensity were taken into account in all analyses. Moreover, market rivalry expectations were included in the models on business expectations (Aparicio et al. 2016; Kelley et al. 2014; Lecuna et al. 2017; Wyrwich et al. 2016; Terjesen and Szerb 2008).

\subsection{Methodology}

We ran generalized linear mixed models with a binary logistic link function in SPSS to test our hypotheses on the entrepreneurial expectations by business life cycle stages.

Multinomial logistic regression with the life cycle stage as dependent variable was run to assess whether entrepreneurial beliefs dilute across the different stages of the entrepreneurial process.

For the mediation analyses, Baron and Kenny's (1986) suggested steps were followed and a bootstrapping method in $\mathrm{R}$ was used (Tingley et al. 2014). The reference category of independent variables is "yes" to the questions in Table 1.

\section{Results}

First, we would like to verify that early stage entrepreneurs' perceived skill level is indeed inflated. Therefore, we compare early stage entrepreneurs to their more experienced peers. The results show that the variation of skill beliefs is very low across the stages of the business life cycle. About $82-85 \%$ of entrepreneurs believe at any stage that they are skilled enough to be in the market. A multinomial logit model (M1: chi-

Table 2 Number and percentage of entrepreneurs with positive beliefs by life-cycle stages

\begin{tabular}{|c|c|c|c|c|}
\hline LICY & & Believe in own entrepreneurial skills & Expect high growth & Believe in offering NewP \\
\hline \multirow[t]{2}{*}{ Nascent entrepreneurs } & Count & 7616 & 1885 & 4270 \\
\hline & $\%$ & $82.4 \%$ & $20.0 \%$ & $45.2 \%$ \\
\hline \multirow[t]{2}{*}{ Baby entrepreneurs } & Count & 6941 & 709 & 3038 \\
\hline & $\%$ & $84.9 \%$ & $8.5 \%$ & $36.6 \%$ \\
\hline \multirow[t]{2}{*}{ Established entrepreneurs } & Count & 17489 & 589 & 5154 \\
\hline & $\%$ & $81.5 \%$ & $2.7 \%$ & $23.5 \%$ \\
\hline \multirow[t]{2}{*}{ Total } & Count & 32046 & 3183 & 12462 \\
\hline & $\%$ & $82.4 \%$ & $8.0 \%$ & $31.4 \%$ \\
\hline
\end{tabular}


square $(88)=9569.563, p<.001$, Nagelkerke R-square $=.286$ ) revealed that nascent entrepreneurs - even if they hardly have any entrepreneurial experience and their new venture has hardly generated any incomeare as confident of their entrepreneurial skills as the owners of established businesses $(\mathrm{B}=.082, p>.05)$. The owners of baby businesses are even more likely to think that they are skilled enough to start a business than their more experienced peers $(B=-.156, p<.001)$. Baby business owners' perceived skill level is also higher than nascent entrepreneurs' $(B=-.238, p<$ .001 ; Table 3 ). A binary logistic regression model reinforced that early stage entrepreneurs are more confident in their entrepreneurial skills than the owners of established businesses (M2: chi-square (41) = 6665.663, $p<.001 ; B=-.085, p<.05$; Table 3).

These results imply that nascent and baby entrepreneurs are both overconfident. The results also show that the perceived skill level peaks at the baby stage. As we do not have data on the evolution of the actual entrepreneurial skills during the early stages of entrepreneurship and how inflated perceived skills are, based on the results, it is not possible to tell if overconfidence is fading gradually or follows a curvilinear pattern rising a little before declining. Hence, H2 cannot be approved. At the same time, it should not be rejected either. More data would need to examine the exact relationship between actual and perceived entrepreneurial skills.

While the perceived entrepreneurial skill level does not change much, the 5-year-long expectation of high growth declines from 20 to $9 \%$ in about 1-2 years, moving from the nascent to the baby stage. Shortly after, it declines further to $3 \%$. Product novelty expectation also lessens from $45 \%$ through $37 \%$ to $24 \%$ during the business life cycle. According to M1, there is a strong association between the business lifecycle stage, the product novelty expectations and the expected growth of business ventures. Compared to the established entrepreneurs, both nascent $(B=-1.774, p<001)$ and baby businesses $(B=-.808, p<001)$ are highly likely to overestimate their growth potential and the novelty of the offered products or services (nascent: $B=-.605, p<$ 001; baby: $B=-.403, p<001)$.

To test whether early stage entrepreneurs' overconfidence in their entrepreneurial skills is mainly relative or absolute, we test whether the effect of the perceived skills on growth expectation is mediated by the beliefs on competitive advantages. As we supposed that the relative or absolute nature of entrepreneurial overconfidence changes with experience during early stage entrepreneurship, we run this examination by life cycle stages. A binary logistic model indicated (M3: chi-square $(41)=680.055, p<$ $.001)$ that at market entry, perceived entrepreneurial skills positively affect growth expectations $(B=.248$, $p<.01)$. Regressing baby business owners' growth expectations on their perceived skill reveals the same interaction (M4: chi-square $(41)=459.546, p<.001$; $B=.366, p<.01)$. The results also show that believing in one's own skills is coupled with a higher likelihood of assuming that the offered product will be new for at least some consumers both at the nascent (M5: chi-square $(42)=1136.944, p<.001$; $B=.131, p<.05)$ and baby (M6 chi-square $(42)=$ 978.872, $p<.001 ; B=.308, p<.001)$ life cycle stages (Table 3 ).

At the nascent stage, both perceived entrepreneurial skills $(B=.232, p<.01)$ and product novelty expectations $(B=.285, p<.001)$ have a direct significant effect on growth expectations when entering them into the same model (M7: chi-square (43) = 739.905, $p<.001$; Table 3). Moreover, it seems that the presence of product novelty expectation changes only slightly the effect of perceived skills on growth expectations. Indeed, a mediation analysis indicated that product novelty expectations do not mediate the effect of skill beliefs on expected growth (ACME (average $)=0.001332, p>.1)$. Consequently, on average, nascent owners' overconfidence is absolute. They overestimate themselves. Therefore, $\mathrm{H} 1$ is approved.

A model with both skill beliefs and product novelty expectations as independent variables shows that those baby business owners' who assume that they are skilled enough to be in the market are more likely to expect high growth of their venture (M8: chi-square (46) = 562.498, $p<.001 ; B=.322, p<.05$; Table 3). Also, those baby owners who think they can offer something new to their consumers are about twice as likely to expect high growth than their counterparts $(B=.706, p$ $<.001)$. A mediation analysis underpinned that at the baby stage, product novelty expectations partially mediates the effect of skill beliefs on expected growth $($ ACME $($ average $)=0.00254, p<.001)$. In sum, baby entrepreneurs' overconfidence is mainly relative, i.e., they overplace themselves. Thus, H3 is accepted. 


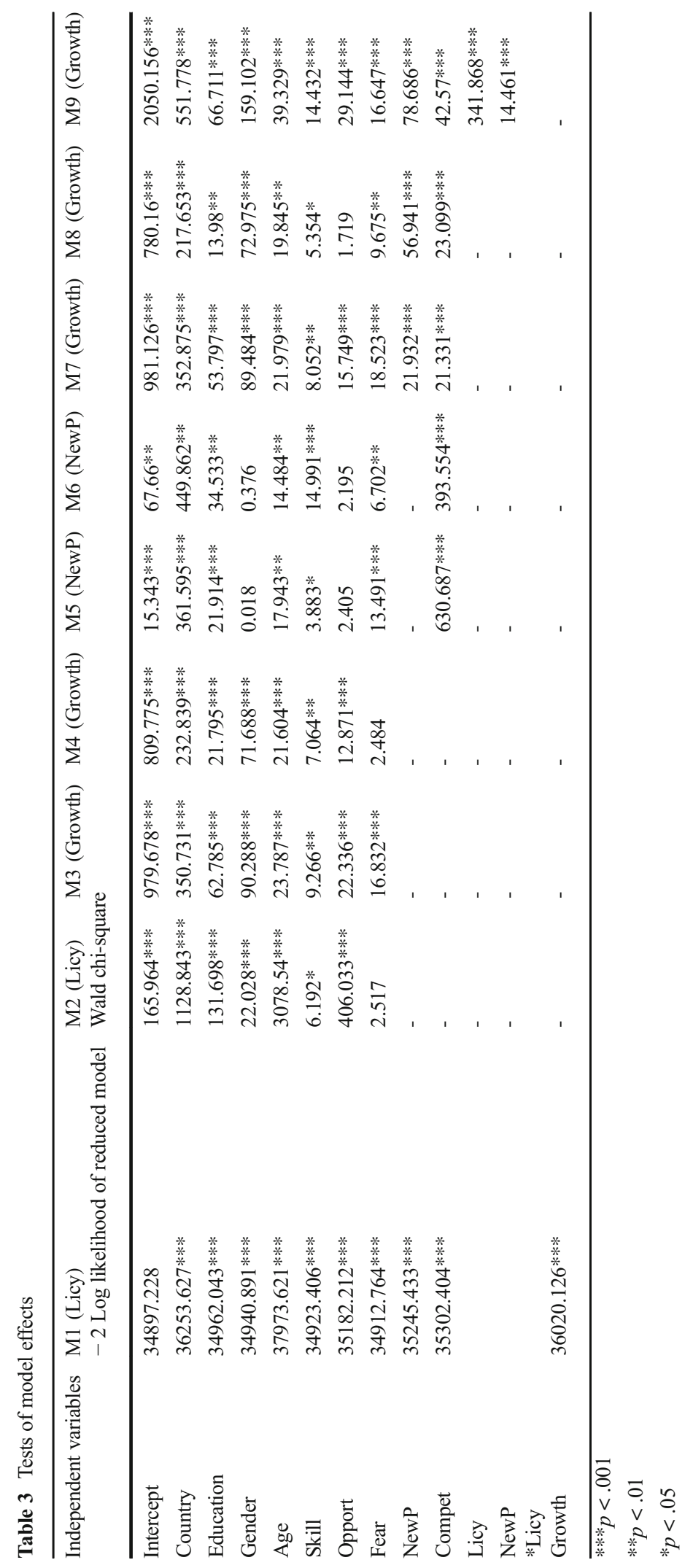


A binary logistic regression also indicated (M9: chisquare $(45)=1691.605, p<.001$; Table 3$)$ that the effect of beliefs on competitive advantages becomes stronger during the early phases of the life cycle. At the nascent stage, not believing to be able to offer something new to the consumers has less negative effect on growth expectations than the model would predict without the life cycle*new product beliefs interaction effect $(B=-.397$, $p<.001)$. Overall, these results indicate that the huge drop in growth expectations is not coupled with a decline of perceived entrepreneurial skills and the effect of product novelty expectations becomes stronger during the early stages of the business life cycle. Thus, H4 is accepted.

\section{Discussion}

The outcomes of our analyses reinforce that the incongruent results on the relationship between perceived entrepreneurial skills and expected and realized growth may be due to the variations in the form of entrepreneurial overconfidence, the actual and perceived skill relationship and the strengthening effect of the more realistic entrepreneurial expectations. Nascent entrepreneurs' overconfidence was revealed to directly influence the expected business growth and it is not mediated by novelty expectations - i.e., the source of competitive advantage. Meanwhile, baby entrepreneurs' overconfidence was found to be partially mediated by their product novelty expectations. Hence, contradicting Cain et al. (2015) and Moore and Cain (2007), our results indicate that nascent entrepreneurs' overconfidence is mostly absolute (see also Bolger et al. 2008) while baby entrepreneurs mainly overplace themselves.

These findings imply that even if market entrants self-select themselves into easy-to-enter fields (see Cain et al. 2015), nascent entrepreneurs still find the start of a venture a relatively difficult task (see Lichtenstein and Fischhoff 1977 on the hard-easy effect). Nevertheless, after surviving the first few months or years in the business - meanwhile seeing many other companies fail-baby business entrepreneurs believe themselves to be relatively successful. As early stage entrepreneurs learn by running their business, they are also supposed to feel that entrepreneurial tasks are less difficult (Frese and Gielnik 2014). Moreover, entrepreneurs revise their skill beliefs based on market feedbacks that contain elements relative to others. As a consequence, at some point, they overplace themselves. This theory of the evolution of the form of overconfidence is in harmony with the theories on entrepreneurs' experiential learning (Frese and Gielnik 2014; Politis 2005) and the results of the psychology of overconfidence; the hard-easy effect (Lichtenstein and Fischhoff 1977) and the forms of overconfidence across task difficulties (Moore and Schatz 2017). Besides, next to the effects of experiential learning, the selection of the less biased entrepreneurs with more genuine growth expectations is likely to contribute to our results.

We could not approve our hypothesis on the gradually fading nature of entrepreneurial overconfidence during the early stages of life cycle. However, the fluctuation of skill beliefs is very low. About the same proportion of entrepreneurs - around 82-85\%-believe at any stage that they are skilled enough to run a business. Thus, based on our framework theory and other theories arguing for the primary role of the learning-bygoing during active entrepreneurship, we can believe that entrepreneurial overconfidence is probably fading. However, further research should verify the exact evolution of perceived and actual entrepreneurial skills.

Further, in line with motivation theories and our fourth hypothesis, our results suggest that perceived skills are important drivers of growth expectations at the early stages of entrepreneurship. However, the huge decline in growth expectations is not the direct consequence of a drop in perceived entrepreneurial skills but it is a result of several factors: expectations on growing market rivalry, declining product novelty projections and other factors represented by the life cycle stage play a powerful role. In theory, the changes in growth expectations attributed here to life cycle stages could be caused by the decline of the real growth potential of the aging ventures too. However, statistical data shows that a very small number-some $2-4 \%$ - of ventures realize more than 10 employees and $50 \%$ growth in 5 years (BERR 2008; Henrekson and Johansson 2010; Nanda 2016). Hence, based on statistical data, it seems again that both nascent and baby entrepreneurs massively overestimate the growth potential of their ventures. In addition, recent studies question whether young firms grow at a faster rate than well established, older companies (Acs et al. 2008; Audretsch 2012; Satterthwaite and Hamilton 2017). It is, therefore, likely that the changes in growth expectations are driven by their gradual adjustment to an increasingly more realistic level. These results mean further support for theories accentuating 
the primary role of experiential learning and feedback processing at the early stages of entrepreneurship.

\section{Summary and conclusions}

Entrepreneurs' skills are believed to be a major factor in the survival and the performance of the business ventures. However, entrepreneurs are often overoptimistic and overconfident about their skills. This is particularly true for early stage entrepreneurs (e.g.: Invernizzi et al. 2016; Koellinger et al. 2007; Ucbasaran et al. 2010). By applying Frese and Gielnik's actioncharacteristics theory (Frese and Gielnik 2014) as the framework of our analyses and comparing differently experienced entrepreneurs, we have produced new empirical evidence about the effect of experience on the relationship between perceived entrepreneurial skills and growth expectations. Thus, our research uncovered a small part of the entrepreneurial "black box" (See Bosma et al. 2012) in several respects.

First, our results shed more light on that perceptions may not reflect actual abilities. Research and theories should take into consideration that perceived skills may be inflated. When the outcome of actions depends not only on own skills but on others' skills too-such as in entrepreneurship where the skill level of competitors has a major influence on the growth of ventures - theory and research should account for the form of overconfidence and assess how the perceived level of own skill relates to the perceived skills of others. Second, our study indicates that distinguishing beliefs from expectations on action outcomes is also essential. Third, our paper draws attention to the significance of differentiating the forms of overconfidence typically confused in the entrepreneurship research. We think that it is the most important novelty of this paper. Fourth, our results emphasize the importance of considering the experience gained by the owners in running their venture when analyzing the effect of entrepreneurial perceptions and expectations. There are considerable differences even between baby and nascent entrepreneurs. Therefore, it seems that the widely used total early phased (TEA) rate (see Bosma et al. 2012) as a general entrepreneurship activity measure would better fit the data and reflect real entrepreneurial activities if it were cut into two parts: nascent and baby businesses.

Furthermore, based on our results, we can formulate some implications for policy makers and practitioners.
Reaching out to the larger public to make entrepreneurial beliefs and expectations more realistic in the early stage of entrepreneurship would prevent a lot of disappointment. Policy makers could found programs that support new venture owners to appropriately evaluate their skills and the expected outcome of their business. Experiential learning programs could be realized by offering trainings within real companies or mentorship and guidance via advisory groups of experienced entrepreneurs. Our results suggest that nascent entrepreneurs focus on themselves and neglect their reference group. Thus, programs should promote more information collection on available products and services on the market, thinking relative to the competitors-on competitive advantages - and considering different sources of objective data, such as survivor rates. Spreading knowledge on employable methods to identify biased decision and thinking - such as elaborating outside views or case-based reasoning (Lovallo et al. 2012) - may result in better founded entrepreneurial decisions and expectations.

Our study also has some limitations. First, GEM APS data does not allow the comparison of expected and realized growth at the business level. Further research should examine the link between growth expectations and actual growth on a micro-level and how the microlevel effects add together to macro, regional, or national level. Based on previous results, it seems possible that biased decisions and exaggerated growth expectations may cause disappointment in the subsequent performance and failure of the business venture (Shepherd et al. 2016; Simon and Shrader 2012). However, overconfidence, up to a point at least, may function as a useful, fast and frugal heuristic (see Gigerenzer and Gaissmaier 2011).

Moreover, the results are based on single constructs. Hence, experiments using standardized methodologies to assess overconfidence and its form could complement our study. Second, we have run cross-sectional analyses. Thus, we were able to formulate our hypotheses solely on associations, and not on causations. Longitudinal studies showing the effect of experiential learning and the profound selection period during the early stages of ventures could yield in interesting additional results.

Also, our results show that a relatively high number of nascent entrepreneurs expect high growth even if they think they are not skilled enough to be on the market. It would be motivating to have more insight into what the other important drivers of nascent entrepreneurs' 
exaggerated growth expectations are. For example, does confirmation bias or illusion of control play a role in nascent entrepreneurs' exaggerated growth expectations? We know very little about those biases at market entry. We have also very little information on how the role of specific heuristics changes along the business life cycle. This would also be an attracting research path to follow.

Finally, our research is limited to the innovationdriven economies. It would be interesting to see how overconfidence functions in other economies and varies across them.

Funding information Open access funding provided by University of Pécs. The research was financed by the Higher Education Institutional Excellence Programme of the Ministry of Human Capacities in Hungary, within the framework of the 4th thematic program "Enhancing the Role of Domestic Companies in the Reindustrialization of Hungary" of the University of Pécs (reference number of the contract: 20765-3/2018/FEKUTSTRAT) and by National Scientific Research Fund of Hungary (OTKA/NKFI grant no. 120289 titled as Entrepreneurship and Competitiveness investigations in Hungary based on the Global Entrepreneurship Monitor surveys 2017-2019).

Open Access This article is distributed under the terms of the Creative Commons Attribution 4.0 International License (http:// creativecommons.org/licenses/by/4.0/), which permits unrestricted use, distribution, and reproduction in any medium, provided you give appropriate credit to the original author(s) and the source, provide a link to the Creative Commons license, and indicate if changes were made.

\section{References}

Acs, Z. J., Parsons, W., \& Tracy, S. (2008). High-impact firms: Gazelles revisited. Washington, DC: Corporate Research Board.

Acs, Z. J., Autio, E., \& Szerb, L. (2014). National Systems of Entrepreneurship: measure issues and policy implications. Research Policy, 43(3), 476-494.

Acs, Z., Estrin, S., Mickiewicz, T. M., and Szerb, L. (2018). Entrepreneurship, institutional economics and economic growth: a systems perspective. In Academy of Management Proceedings (Vol. 2018, No. 1, p. 12774). Briarcliff Manor, NY: Academy of Management.

Aparicio, S., Urbano, D., \& Audretsch, D. (2016). Institutional factors, opportunity entrepreneurship and economic growth: Panel data evidence. Technological Forecasting and Social Change, 102, 45-61.

Åstebro, T., Herz, H., Nanda, R., \& Weber, R. A. (2014). Seeking the roots of entrepreneurship: Insights from behavioural economics. Journal of Economic Perspectives, 28(3), 49-70.

Audretsch, D. B. (2012). Determinants of high-growth entrepreneurship. OECD/DBA report. http://www. oecd. org/cfe/
leed/Audretsch_determinants $\%$ 20of\% 20high-growth\% 20firms. Accessed 06 February 2019.

Autio, E. (2011). High-aspiration entrepreneurship. In M. Minniti (Ed.), The Dynamics of Entrepreneurship (pp. 251-276). Oxford, UK: Oxford University Press.

Bandura, A. (2006). Guide for constructing self-efficacy scales. Self-efficacy Beliefs of Adolescents, 5, 307-337.

Barbosa, S. D., Gerhardt, M. W., \& Kickul, J. R. (2007). The role of cognitive style and risk preference on entrepreneurial selfefficacy and entrepreneurial intentions. Journal of Leadership and Organizational Studies, 13(4), 86-104.

Baron, R. A. (1998). Cognitive mechanisms in entrepreneurship: why and when entrepreneurs think differently than other people. Journal of Business Venturing, 13(4), 275-294.

Baron, R. A., \& Markman, G. D. (2005). Toward a process view of entrepreneurship: the changing impact of individual level variables across phases of new venture development. Current Topics in Management, 9, 45-64.

Baron, R. M., \& Kenny, D. A. (1986). The moderator-mediator variable distinction in social psychological research: Conceptual, strategic, and statistical considerations. Journal of Personality and Social Psychology, 51(6), 1173.

Betzer, A., van den Bongard, I., Theissen, E., and Volkmann, C. (2017). All is not lost that is delayed: overconfidence and investment failure. https://www.eurofidai. org/sites/default/files/pdf/parismeeting/2017/theissen_2017. pdf. Accessed 06 February 2019.

Bolger, F., Pulford, B. D., \& Colman, A. M. (2008). Market entry decisions: effects of absolute and relative confidence. Experimental Psychology, 55, 113-120.

Bosma, N., \& Schutjens, V. (2009). Determinants of early-stage entrepreneurial activity in European regions; distinguishing low and high ambition entrepreneurship. In D. Smallbone, H. Landstrom, \& D. J. Evans (Eds.), Making the difference in local, regional and national economies: frontiers in European entrepreneurship research (pp. 49-77). London, UK: Edward Elgar.

Bosma, N., Coduras, A., Litovsky, Y., and Seaman, J. (2012). GEM manual: a report on the design, data and quality control of the Global Entrepreneurship Monitor. Global Entrepreneurship Monitor, 1-95.

Cain, D. M., Moore, D. A., \& Haran, U. (2015). Making sense of overconfidence in market entry. Strategic Management Journal, 36(1), 1-18.

Camerer, C., \& Lovallo, D. (1999). Overconfidence and excess entry: an experimental approach. The American Economic Review, 89(1), 306-318.

Chamorro-Premuzic, T. (2013). Confidence: overcoming low selfesteem, insecurity, and self-doubt. London: Penguin.

Chi, M. T. H., Glaser, R., \& Rees, E. (1982). Expertise in problem solving. In R. J. Stemberg (Ed.), Advances in the psychology of human intelligence (Vol. 1, pp. 7-75). Hillsdale, NJ: Erlbaum.

Cooper, A. C., Woo, C. Y., \& Dunkelberg, W. C. (1988). Entrepreneurs' perceived chances for success. Journal of Business Venturing, 3(2), 97-108.

Cope, J., \& Watts, G. (2000). Learning by doing-an exploration of experience, critical incidents and reflection in entrepreneurial learning. International Journal of Entrepreneurial Behavior \& Research, 6(3), 104-124. 
Costa, D. F., de Melo Carvalho, F., de Melo Moreira, B. C., \& do Prado, J. W. (2017). Bibliometric analysis on the association between behavioural finance and decision making with cognitive biases such as overconfidence, anchoring effect and confirmation bias. Scientometrics, 111(3), 1775-1799.

Department for Business Enterprise and Regulatory Reform (BERR). (2008). High growth firms in the United Kingdom: lessons from an analysis of comparative UK performance. BERR Economics Paper No.3. http://webarchive. nationalarchives.gov.uk/+/http:/www.bis.gov. uk/files/file49042.pdf. Accessed 06 February 2019.

Everett, C. R., \& Fairchild, R. J. (2015). A theory of entrepreneurial overconfidence, effort, and firm outcomes. Journal of Entrepreneurial Finance, 17, 1-26.

Fishbein, M., \& Ajzen, I. (2011). Predicting and changing behavior: The reasoned action approach. Psychology press.

Forbes, D. P. (2005). Are some entrepreneurs more overconfident than others? Journal of Business Venturing, 20(5), 623-640.

Foss, N. J., \& Klein, P. G. (2012). Organizing entrepreneurial judgment: a new approach to the firm. Cambridge, UK: Cambridge University Press.

Frese, M., \& Gielnik, M. M. (2014). The psychology of entrepreneurship. Annual Revew of Organisational Psycholy and Organal Behaviour, 1(1), 413-438.

Fuller, B., Liu, Y., Bajaba, S., Marler, L. E., \& Pratt, J. (2018). Examining how the personality, self-efficacy, and anticipatory cognitions of potential entrepreneurs shape their entrepreneurial intentions. Personality and Individual Differences, $125,120-125$.

Gartner, W. B., Bird, B. J., \& Starr, J. A. (1992). Acting as if: differentiating entrepreneurial from organizational behavior. Entrepreneurship Theory and Practice, 16(3), 13-32.

Gervais, S., \& Odean, T. (2001). Learning to be overconfident. The Review of Financial Studies, 14(1), 1-27.

Gigerenzer, G., \& Gaissmaier, W. (2011). Heuristic decision-making. Annual Review of Psychology, 62, 451-482.

Grichnik, D. (2008). Risky choices in new venture decisionsexperimental evidence from Germany and the United States. Journal of International Entrepreneurship, 6(1), 22-47.

Gutierrez, C., and Astebro, T. (2016). The impact of overconfidence on excess entry. In Academy of Management Proceedings (Vol. 2016, No. 1, p. 14138). Academy of Management.

Hall, R. E., \& Woodward, S. E. (2010). The burden of the nondiversifiable risk of entrepreneurship. American Economic Review, 100(3), 1163-1194.

Hayward, M. L., Shepherd, D. A., \& Griffin, D. (2006). A hubris theory of entrepreneurship. Management Science, 52(2), 160-172.

Hayward, M. L., Forster, W. R., Sarasvathy, S. D., \& Fredrickson, B. L. (2010). Beyond hubris: how highly confident entrepreneurs rebound to venture again. Journal of Business Venturing, 25(6), 569-578.

Henrekson, M., \& Johansson, D. (2010). Gazelles as job creators: a survey and interpretation of the evidence. Small Business Economics, 35(2), 227-244.

Hermans, J., Vanderstraeten, J., van Witteloostuijn, A., Dejardin, M., Ramdani, D., \& Stam, E. (2015). Ambitious entrepreneurship: a review of growth aspirations, intentions, and expectations. In Entrepreneurial growth: Individual, firm, and region (pp. 127-160). Bingley, UK: Emerald Group Publishing Limited.

Hershey, D. A., Jacobs-Lawson, J. M., \& Walsh, D. A. (2003). Influences of age and training on script development. Aging, Neuropsychology, and Cognition, 10(1), 1-19.

Hogarth, R. M., \& Karelaia, N. (2012). Entrepreneurial success and failure: confidence and fallible judgment. Organization Science, 23(6), 1733-1747.

Invernizzi, A. C., Menozzi, A., Passarani, D. A., Patton, D., \& Viglia, G. (2016). Entrepreneurial overconfidence and its impact upon performance. International Small Business Journal, 35(6), 709-728.

Johnson-Laird, P.N. (2005). Mental models and reasoning in K.J. Holyoak and R.G. Morrison RG (Eds.), The Cambridge handbook of thinking and reasoning (pp. 185-209). Cambridge University Press.

Jovanovic, B. (1982). Selection and the evolution of industry. Econometrica, 50, 649-670.

Kelley, D. J., Ali, A., and Lee, C. (2014). Growth intentions as a function of personal resources and opportunity perceptions. In ICSB World Conference Proceedings. International Council for Small Business (ICSB).

Koellinger, P., Minniti, M., \& Schade, C. (2007). "I think I can, I think I can": overconfidence and entrepreneurial behaviour. Journal of Economic Psychology, 28(4), 502-527.

Konon, A., and Kritikos, A. (2015). Entrepreneurial decision making, personality traits and subjective learning. Cesifogroup.de. Accessed 06 February 2019.

Kugler, T., Kausel, E. E., \& Kocher, M. G. (2012). Are groups more rational than individuals? A review of interactive decision making in groups. Wiley Interdisciplinary Reviews: Cognitive Science, 3(4), 471-482.

Lecuna, A., Cohen, B., \& Chavez, R. (2017). Characteristics of high-growth entrepreneurs in Latin America. International Entrepreneurship and Management Journal, 13(1), 141159.

Lee, C., Hallak, R., \& Sardeshmukh, S. R. (2016). Innovation, entrepreneurship, and restaurant performance: a higher-order structural model. Tourism Management, 53, 215-228.

Levie, J., and Autio, E. (2013). Growth and growth intentions. White Paper. ht t p:// w w w. v l a i . be/sites/default/files/documenten/2013_autio_-_growth and_growth_intentions_-_whitepaper.pdf. Accessed $0 \overline{6}$ February 2019.

Lichtenstein, S., \& Fischhoff, B. (1977). Do those who know more also know more about how much they know? Organizational Behaviour and Human Decision Processes, 20(2), 159-183.

Lovallo, D., Clarke, C., \& Camerer, C. (2012). Robust analogizing and the outside view: two empirical tests of case-based decision making. Strategic Management Journal, 33(5), 496-512.

Lowe, R. A., \& Ziedonis, A. A. (2006). Overoptimism and the performance of entrepreneurial firms. Management Science, 52(2), 173-186.

Malmendier, U., \& Tate, G. (2015). Behavioural CEOs: the role of managerial overconfidence. Journal of Economic Perspectives, 29, 37-60.

Markman, G. D., Balkin, D. B., \& Baron, R. A. (2002). Inventors and new venture formation: the effects of general selfefficacy and regretful thinking. Entrepreneurship Theory and Practice, 27(2), 149-165. 
Miao, C., Qian, S., \& Ma, D. (2017). The relationship between entrepreneurial self-efficacy and firm company performance: a meta-analysis of main and moderator effects. Journal of Small Business Management, 55(1), 87-107.

Minniti, M., \& Bygrave, W. (2001). A dynamic model of entrepreneurial learning. Entrepreneurship Theory and Practice, 25(3), 5-16.

Moore, D. A., \& Cain, D. M. (2007). Overconfidence and underconfidence: when and why people underestimate (and overestimate) the competition. Organizational Behaviour and Human Decision Processes, 103(2), 197-213.

Moore, D. A., \& Healy, P. J. (2008). The trouble with overconfidence. Psychological Review, 115(2), 502.

Moore, D. A., \& Schatz, D. (2017). The three faces of overconfidence. Social and Personality Psychology Compass. https://doi.org/10.1111/spc3.12331.

Muthukrishna, M., Henrich, J., Toyokawa, W., Hamamura, T., Kameda, T., \& Heine, S. J. (2018). Overconfidence is universal? Elicitation of Genuine Overconfidence (EGO) procedure reveals systematic differences across domain, task knowledge, and incentives in four populations. PloS one, 13(8), e0202288.

Nanda, R. (2016). Financing high-potential entrepreneurship. IZA World of. Labour. https://doi.org/10.15185/izawol.252.

Navis, C., \& Ozbek, O. V. (2017). Why context matters: overconfidence, narcissism, and the role of objective uncertainty in entrepreneurship. Academy of Management Review, 42(1), 148-153.

Newmann, A., Obschonkab, M., Schwarzc, S., Cohena, M., \& Nielsena, I. (2018). Entrepreneurial self-efficacy: a systematic review of the literature on its theoretical foundations, measurement, antecedents, and outcomes. Journal of Vocational Behavior. https://doi.org/10.1016/j. jvb.2018.05.012.

Piperopoulos, P., \& Dimov, D. (2015). Burst bubbles or build steam? Entrepreneurship education, entrepreneurial self-efficacy, and entrepreneurial intentions. Journal of Small Business Management, 53(4), 970-985.

Politis, D. (2005). The process of entrepreneurial learning: a conceptual framework. Entrepreneurship Theory and Practice, 29(4), 399-424.

Porter, M. E. (1985). Competitive advantage: creating and sustaining superior performance. New York: Free Press.

Quatraro, F., \& Vivarelli, M. (2014). Drivers of entrepreneurship and post-entry performance of newborn firms in developing countries. The World Bank Research Observer, 30(2), 277305.

Rauch, A., \& Frese, M. (2007). Let's put the person back into entrepreneurship research: a meta-analysis on the relationship between business owners' personality traits, business creation, and success. European Journal of Work and Organizational Psychology, 16(4), 353-385.

Reynolds, P., Bosma, N., Autio, E., Hunt, S., De Bono, N., Servais, I., \& Chin, N. (2005). Global entrepreneurship monitor: data collection design and implementation 1998-2003. Small Business Economics, 24(3), 205-231.
Satterthwaite, S., \& Hamilton, R. T. (2017). High-growth firms in New Zealand: superstars or shooting stars? International Small Business Journal, 35(3), 244-261.

Shane, S. A. (2003). A general theory of entrepreneurship: the individual-opportunity nexus. Cheltenman, UK: Edward Elgar Publishing.

Shepherd, D. A. (2009). Commitment and performance: make your failures pay off for you! London, UK: Pearson Education.

Shepherd, D. A., Williams, T., Wolfe, M., \& Patzelt, H. (2016). Learning from entrepreneurial failure. Cambridge, UK: Cambridge University Press.

Simon, M., \& Houghton, S. M. (2003). The relationship between overconfidence and the introduction of risky products: evidence from a field study. Academy of Management Journal, 46(2), 139-149.

Simon, M., \& Shrader, R. C. (2012). Entrepreneurial actions and optimistic overconfidence: the role of motivated reasoning in new product introductions. Journal of Business Venturing, 27(3), 291-309.

Stenholm, P., Acs, Z. J., \& Wuebker, R. (2013). Exploring country-level institutional arrangements on the rate and type of entrepreneurial activity. Journal of Business Venturing, 28, 176-193.

Terjesen, S., \& Szerb, L. (2008). Dice thrown from the beginning? An empirical investigation of determinants of firm level growth expectations. Estudios de Economia, 35(2), 153-178.

Tingley, D., Yamamoto, T., Hirose, K., Keele, L., \& Imai, K. (2014). Mediation: R package for causal mediation analysis. Journal of Statistical Software, 59(5).

Tominc, P., \& Rebernik, M. (2007). Growth aspirations and cultural support for entrepreneurship: a comparison of postsocialist countries. Small Business Economics, 28(2), 239255.

Trevelyan, R. (2011). Self-regulation and effort in entrepreneurial tasks. International Journal of Entrepreneurial Behavior and Research, 17(1), 39-63.

Ucbasaran, D., Westhead, P., Wright, M., \& Flores, M. (2010). The nature of entrepreneurial experience, business failure and comparative optimism. Journal of Business Venturing, 25(6), 541-555.

Wu, B., \& Knott, A. M. (2006). Entrepreneurial risk and market entry. Management Science, 52(9), 1315-1330.

Wyrwich, M., Stuetzer, M., \& Sternberg, R. (2016). Entrepreneurial role models, fear of failure, and institutional approval of entrepreneurship: a tale of two regions. Small Business Economics, 46(3), 467-492.

Zhang, S. X., \& Cueto, J. (2017). The study of bias in entrepreneurship. Entrepreneurship Theory and Practice, 41(3), 419454.

Publisher's note Springer Nature remains neutral with regard to jurisdictional claims in published maps and institutional affiliations. 